\title{
Waste Water Treatment Using Eco Friendly Oxidising Agent Fe (VI)
}

\section{Vidyavati Shastry* and Shashidhar S}

Department of Chemistry, SEA College of engineering and Technology, Bangalore, India

\begin{abstract}
Ferrate $(\mathrm{Fe}(\mathrm{VI}))$ is a potential water treatment chemical due to its dual functions as an oxidant and a subsequent coagulant/precipitant as ferric hydroxide. Hence, an application of $\mathrm{Fe}(\mathrm{VI})$ to wastewater could achieve both oxidative elimination of various micro pollutants and reduction in the COD, BOD, Total hardness, Chloride, Fluoride can be achieved.

The aim of this study was to assess the potential of $\mathrm{Fe}(\mathrm{VI})$ to oxidize selected micro pollutants and remove phosphate during enhanced treatment of municipal waste water in a single treatment step. The waste water from pond in K.R Puram, Bangalore is treated with powerful eco-friendly oxidizing agent $\mathrm{Fe}(\mathrm{VI})\{0.005 \mathrm{mg} / \mathrm{L}\}$, the parameters such as, COD, BOD,TSS, Total hardness, chloride, phosphate, ammonia, cyanide etc. are measured before and after treatment. The reduction in the COD, BOD, Total hardness, Phosphate, Ammonia, Cyanides are observed.
\end{abstract}

Keywords: Waste water; Fe (VI); Pollutants

\section{Introduction}

Water pollution is a serious issue which affects the physical and economic health of world community. According to W.H.O million of people suffer illness and death each year due to drinking water contamination. Filtration and disinfection methods are followed in water treatment. But filtration is poor barrier for few pollutants. Disinfection by chemicals gives by-products some of which may be toxic to human and aquatic health.

In recent years Ferrate (VI) has attained importance as environmentally friendly oxidizing agent and coagulating agent [1] in wastewater treatment. The product Fe (III) is non toxic compound. Fe (VI) oxidizes toxic chemicals [2], nitrites, glycerol, oxalates, alcohol, sulphides [3] ether, ammonia [4], urea, many other water soluble and water insoluble organic compounds, drugs [5] microbes etc., in the $\mathrm{pH}$ range of 6-9. It simultaneously acts as oxidant disinfectant \& coagulant in water treatment.

$\mathrm{Fe}(\mathrm{VI})$ is powerful reducing agent it reduces in acids and alkalis.

$$
4 \mathrm{~K}_{2} \mathrm{FeO}_{4}+10 \mathrm{H}_{2} \mathrm{O} \rightarrow 4 \mathrm{Fe}(\mathrm{OH})_{3}+3 \mathrm{O}_{2}+8 \mathrm{KOH}
$$

When waste water is treated with Fe (VI) concentrations higher than $5 \mathrm{mg} / \mathrm{L}$, it eliminates the organic compounds by more than $60 \%$. It removes phosphates [6] from 2.5 to $0.80 \mathrm{mg}$ when the dose of Fe (VI) is more than $7 \mathrm{mg} / \mathrm{L}$. It oxidises $\mathrm{H}_{2} \mathrm{~S}$ to thiosulphate and sulphate at $\mathrm{pH}$ 9-11. $\mathrm{H}_{2} \mathrm{~S}$ is formed by the incomplete oxidation of organic compounds which gives bad odour to water and has toxic nature. The oxidation of organic pollutants by Fe (VI) incorporated by nature and manmade activities reduces the $\mathrm{COD}$ and $\mathrm{BOD}$ of water samples.

$$
\begin{aligned}
& 3 \mathrm{C}_{6} \mathrm{H}_{5} \mathrm{CH}_{2} \mathrm{OH}+2 \mathrm{~K}_{2} \mathrm{FeO}_{4} \rightarrow 3 \mathrm{C}_{6} \mathrm{H}_{5} \mathrm{CHO}+\mathrm{Fe}_{2} \mathrm{O}_{3}+4 \mathrm{KOH}+\mathrm{H}_{2} \mathrm{O} \\
& 8 \mathrm{HFeO}_{4}^{-}+3 \mathrm{H}_{2} \mathrm{~S}+6 \mathrm{H}_{2} \mathrm{O} \rightarrow 8 \mathrm{Fe}(\mathrm{OH})_{3}+3 \mathrm{SO}_{4}{ }^{2-}+2 \mathrm{OH}^{-}
\end{aligned}
$$

The level of BOD and COD is an important factor in evaluating the organic pollutants in waste water. The discharge of impurities generate BOD \& COD level to 5000-3000 mg/L and COD level to 1000-5000mg/ $\mathrm{L}$ but discharge permits only $250 \mathrm{mg} / \mathrm{L} \& 500 \mathrm{mg} / \mathrm{L}$ respectively.

The aim of our study is to check the water quality in pond and to treat it with $\mathrm{Fe}(\mathrm{VI})$ to remove the pollutants.

\section{Experimental}

\section{Preparation of Fe (VI)}

All chemicals used were of analytical grade (EMerck) and were used without further purifications. To the $250 \mathrm{ml}$ sodium hypochlorite solution slowly added $25 \mathrm{~g}$ of ferric nitrate at 25-30 degrees. The temperature is maintained at 30 degrees while saturating with $\mathrm{NaOH}$. The mixture is then filtered with suction through a coarse fritted glass filter. The sodium ferrate filtrate is placed in a $250 \mathrm{ml}$ beaker and immersed in a 20 degree water bath $100 \mathrm{ml}$ of saturated $\mathrm{KOH}$ solution is added with stirring. Stirring is continued for 5 minutes, finally filtering through a fritted glass filter of medium porosity, the filtrate being discarded [7].

The precipitate is leached on the filter with $4-510 \mathrm{ml}$ portions of 3 molar $\mathrm{KOH}$ solutions. The residue remaining on the filter has a light grey cast and is discarded. The filtrate is transferred to a $250 \mathrm{ml}$ beaker and $50 \mathrm{ml}$ of chilled, saturated $\mathrm{KOH}$ solution is added. Any solid potassium ferrate still on the filter disk is washed out with a few $\mathrm{ml}$ of saturated $\mathrm{KOH}$ solution. The final solution is approximately 11 molar in $\mathrm{KOH}$. The solution is stirred for 5 minutes and then filtered through medium porosity fritted glass.

\section{Waste water treatment with Fe (VI)}

Water sample is collected in polythene bottles from the pond in K.R Puram, Bangalore, INDIA.Water is passed through a series of process of primary treatment to remove suspended \& colloidal impurities. Then it is treated with Fe (VI) over a period of 25-30 days. The water parameters are recorded regularly.

*Corresponding author: Dr.Vidyavati Shastry, Department of Chemistry, SEA College of engineering and Technology, Bangalore, India, E-mail: vidyavati_ kinetic@yahoo.co.in

Received July 29, 2011; Accepted December 08, 2011; Published December 12, 2011

Citation: Shastry V, Shashidhar S (2011) Waste Water Treatment Using Eco Friendly Oxidising Agent Fe (VI). Hydrol Current Res 2:123. doi:10.4172/21577587.1000123

Copyright: ( 2011 Shastry V, et al. This is an open-access article distributed under the terms of the Creative Commons Attribution License, which permits unrestricted use, distribution, and reproduction in any medium, provided the original author and source are credited. 
Primary treatment: The treatment process consists of many steps (i) Physical process which include sedimentation and filtration (ii) Chemical process includes precipitation chemical coagulation followed by settling and mixed media filtration.

Microstraining: It is a special type of filtration procedure which makes use of filters oven from stainless steel wires with opening only 60-70 $\mu \mathrm{m}$ across to remove very small particles. High flow rates and low back pressures are normally achieved.

Coagulation and flocculation: The object of coagulation is to alter these particles in such a way as to allow them to adhere to each other. Most colloids of interest in water treatment remain suspended in solution because they have a net negative surface charge that causes the particles to repel each other. The intended action of the coagulant is to neutralise that charge, allowing the particles to come together to form larger particles that can be more easily removed from the raw water. The usual coagulant is alum $\left[\mathrm{Al}_{2}\left(\mathrm{SO}_{4}\right)_{2} \bullet 18 \mathrm{H}_{2} \mathrm{O}\right]$ Alum when added to water, the aluminium in this salt hydrolyses by reactions that consume. The gelatinous hydroxide thus formed carries suspended material with it as it settles down.

Then the water is analysed to determine the parameters such as COD, BOD, Sulphide, phosphate, Chloride, Cyanide, Ammonia, Hardness, Pesticides etc and Listed in Table 1.

Then the Waste water is collected in different containers and treated with $\mathrm{Fe}(\mathrm{VI})$ with Concentration from 0.001 to 0.1 at $\mathrm{pH}-9$.

\section{Determination of BOD}

BOD of water sample is measure of quantity of oxygen required by micro organisms to oxidize organic wastes present in waste water over a period of five days at $20^{\circ} \mathrm{C}$.

The BOD of waste water is treated with $\mathrm{Fe}$ (VI) before the treatment. Then waste water is treated with $\mathrm{Fe}(\mathrm{VI})\{0.005 \mathrm{mg} / \mathrm{L}\}$ at $\mathrm{pH}$ 9. The BOD of treated water is determined [8] at intervals of 5 days. The results are listed in Table 3.

The dissolved oxygen forms the basis for the biological oxygen demand (BOD) which is a parameter to evaluate organic wastes in a water samples.

$300 \mathrm{ml}$ of water sample is pipette into a clean conical flask into a clean glass stoppered bottle, $3 \mathrm{ml}$ of maganous sulphate solution is

\begin{tabular}{|l|l|l|}
\hline SL.NO & Parameters & $\begin{array}{l}\text { Before Treatment } \\
\mathrm{mg} / \mathrm{L}\end{array}$ \\
\hline 1 & Colour & Blackish \\
\hline 2 & Odour & Pungent \\
\hline 3 & COD & 151.3 \\
\hline 4 & BOD & 20.0 \\
\hline 5 & Suspended Solids & 158.1 \\
\hline 6 & Phosphate & 3.5 \\
\hline 7 & Sulphide & 100.2 \\
\hline 8 & Chloride & 350.8 \\
\hline 9 & Cyanide & 0.07 \\
\hline 10 & Ammonia & 29.5 \\
\hline 11 & Total Hardness & 700.7 \\
\hline 12 & Arsenic & 0.06 \\
\hline 13 & Pesticides & 0.042 \\
\hline
\end{tabular}

Table 1: Analysis of sample water before treatment.

\begin{tabular}{|l|l|l|l|l|l|}
\hline $\begin{array}{l}\text { Parameters } \\
(\mathbf{m g} / \mathbf{L})\end{array}$ & Day 1 & Day 5 & Day 10 & Day 15 & Day 25 \\
\hline Colour & - & - & Diminishing & Diminishing & Colourless \\
\hline Odour & - & - & Diminishing & Diminishing & Agreeable \\
\hline $\begin{array}{l}\text { Suspended } \\
\text { Solids }\end{array}$ & 150.2 & 144.5 & 138.8 & 131.1 & 124.8 \\
\hline Phosphate & 2.91 & 2.43 & 2.15 & 1.65 & 1.48 \\
\hline Sulphide & 86.4 & 71.7 & 66.3 & 40.1 & 32.5 \\
\hline Chloride & 320 & 314.2 & 306.8 & 298.4 & 255.6 \\
\hline Cyanide & 0.065 & 0.062 & 0.057 & 0.052 & 0.05 \\
\hline Ammonia & 24.2 & 19.4 & 15.3 & 12.7 & 11.3 \\
\hline Total Hardness & 652.6 & 554.8 & 528.7 & 490.6 & 465.4 \\
\hline Arsenic & 0.055 & 0.052 & 0.049 & 0.045 & 0.04 \\
\hline
\end{tabular}

Table 2: Waste water analysis after treatment with Fe (VI) (0.005mg /L) AT PH -9 .

\begin{tabular}{|l|l|l|l|}
\hline SL. NO & No. of days & BOD $\{\mathbf{m g} / \mathbf{L}\}$ & $\begin{array}{l}\text { COD } \\
\text { [mg/L }\}\end{array}$ \\
\hline 1 & 5 & 20.0 & 151.3 \\
\hline 2 & 10 & 18.3 & 142.6 \\
\hline 3 & 15 & 15.2 & 125.4 \\
\hline 4 & 20 & 13.1 & 116.5 \\
\hline 5 & 25 & 11.5 & 86.2 \\
\hline 6 & 30 & 9.2 & 65.9 \\
\hline
\end{tabular}

Table 3: Variation of cod, bod of waste water with Fe (VI) Treatment.

added slowly \& $3 \mathrm{ml}$ of alkaline potassium iodide solution. Stopper the bottle \& shake well, allow the precipitate to settle one test tube of concentrated sulphuric acid is added slowly \& mixed well to dissolve the precipitate completely. $100 \mathrm{ml}$ of this solution is pipette into a clean conical flask \& titrated slowly against standard sodium thiosulphate solution using $2 \mathrm{ml}$ starch indicator.

The BOD the sample is calculated from the equation

Mass of dissolved oxygen $/ \mathrm{dm}^{3}=$ Normality of oxygen solution ${ }^{\star}$ Equivalent mass of oxygen

\section{Determination of COD}

COD is the amount of oxygen consumed in the chemical oxidation of organic and inorganic wastes present in 1 litre of waste water.

\section{Procedure}

$50 \mathrm{ml}$ of sample was taken into a refluxing flask and several boiling stones were added. $0.1 \mathrm{~g} \mathrm{HgSO}_{4}$ was added to the solution. $5 \mathrm{ml}$ of concentrated $\mathrm{H}_{2} \mathrm{SO}_{4}$ was also added to the solution. To ensure that $\mathrm{HgSO}_{4}$ dissolved completely, the solution was swirled slowly while adding Sulphuric acid. 0.1g of $\mathrm{Ag}_{2} \mathrm{SO}_{4}$ was added to this solution. Finally Potassium dichromate was added. Thorough mixing of the solution was ensured by swirling the flask in a water bath to recover any volatile substances that may have escaped from the liquid state. The flask was then attached to the condenser and further cooling was done. $20 \mathrm{ml}$ of Sulphuric acid was added to the solution in the flask continuing, cooling and swirling to mix the solution. The solution was refluxed for 1hour. A blank run (using $50 \mathrm{ml}$ distilled water instead of sample) was simultaneously conducted with the same procedure after cooling, the solution was transferred to an Erlenmeyer flask.

The reflux flask was rinsed thrice, pouring the rinsing water to the Erlenmeyer flask. The solution was diluted to about $300 \mathrm{ml}$ and about 8 drops of Phenanthroline ferrous sulphate was added to the solution as an indicator. The solution was titrated against the Mohr's salt and the 
titre volume required for the colour change from blue-green to reddish blue was noted. The procedure was repeated for the blank run.

The COD is determined by following formula

$$
\mathrm{COD}=\frac{\mathrm{N}_{\mathrm{FAS}}{ }^{*}(\mathrm{X}-\mathrm{Y})^{\star 8}}{1000}
$$

Where ' $\mathrm{X}-\mathrm{Y}$ ' is amount of potassium dichromate consumed by water.

\section{Determination of total hardness}

The total hardness is due to the presence of bicarbonates sulphates and chlorides of calcium \& magnesium.

These are estimated by titrating a known volume of water sample against standard EDTA using 3-4 drops of eriochrome black indicator in presence of alkali buffer.

\section{Chloride determination}

Chloride is major inorganic anion present in natural and waste waters. A high content of chloride accelerates the corrosion process of metallic pipes and structures. It has harmful effects on agriculture; at high it imparts disagreeable taste to water.

It is estimated by titrating a known volume of water with standard silver nitrate solution using potassium chromate indicator.

\section{Fluoride determination}

Flouride concentration affects water quality. Concentration excess

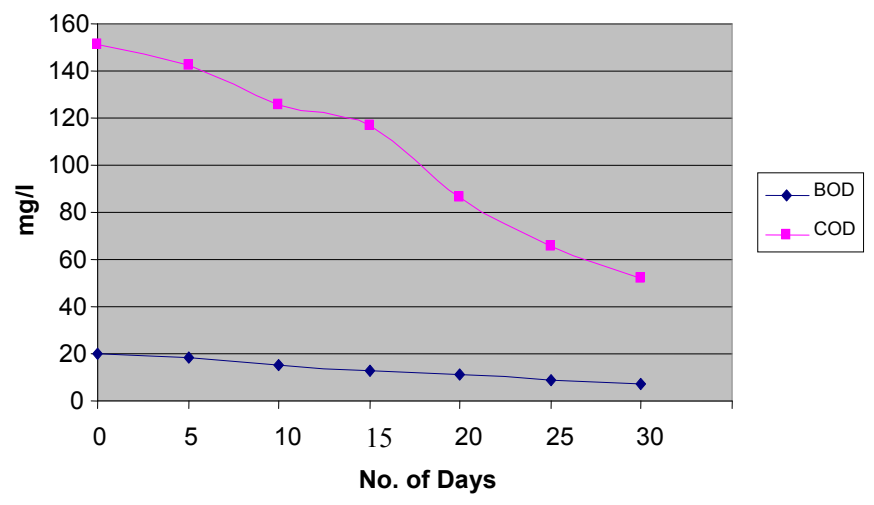

Figure 1: Variation of $\mathrm{COD}, \mathrm{BOD}$ with $\mathrm{Fe}(\mathrm{VI})$ treatment.

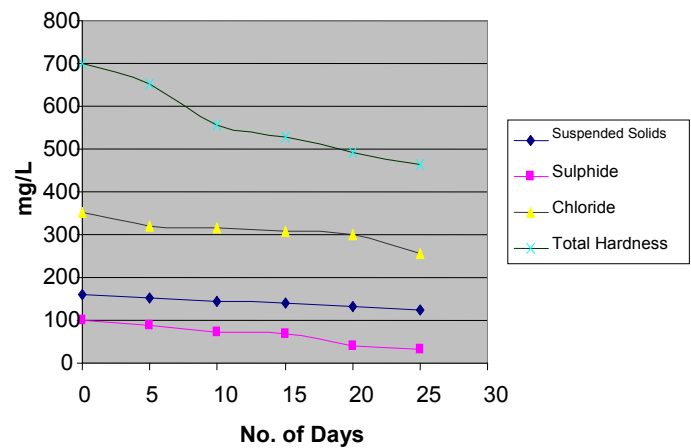

Figure 2: Variation of Suspended Solids, Sulphide, Chloride, Total hardness with $\mathrm{Fe}(\mathrm{VI})$ treatment.

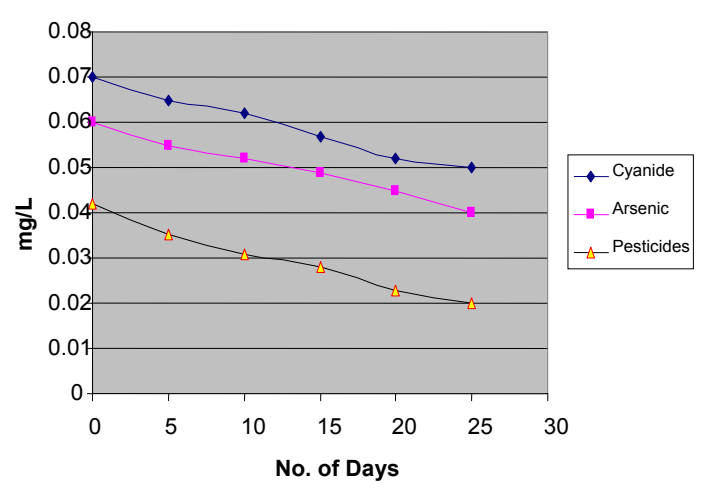

Figure 3: Variation of Cyanide, Arsenic, Pesticides, with Fe (VI) treatment.

of $1 \mathrm{mg} / \mathrm{l}$ causes fluorosis and mottling.It is estimate colorimetrically using SPANDS reagent.

\section{Determination of phosphate}

The phosphate is estimated colometrically using Ammonium molybdate solution in presence of Dihydrogen phosphate sulphuric acid and sodium sulphide solution. The absorbance of solution was measured.

The phosphate estimation may be affected by slight changes in concentrations of reagents and presence of interfering substances.

\section{Results}

The pond water is contaminated by sanitary wastes, plant wastes, detergents \& also by human activities. The water is made free from suspended solids colloidal impurities etc., by primary treatment \& then treated with $\mathrm{Fe}(\mathrm{VI})$ for a period of 30days. The parameters are measured before and after treatment of $\mathrm{Fe}(\mathrm{VI})$ and listed as shown in the following table.

\section{Conclusions}

The study reveals that Fe (VI) replaces several chemical impurities like sulphides, ammonia, phosphate, urea, arsenic, organic compounds, nitrous compounds, organic sulphur compounds etc.,

The aggressive orders are formed by ammonia, sulphides, etc. The Fe (VI) oxidizes Sulphides to Sulphates, Ammonia and nitrous compounds to nitrates which can be precipitated as non hazardous Iron compounds which diminishes the disagreeable smell. The coloured compounds are oxidises hence the colour also diminishes after the treatment. Thus the waste water can be treated with Fe (VI) which forms non hazardous by products. The phosphate is removed in the form of Ferric phosphates. The reduction in COD, BOD results by the oxidation of organic compounds.

It is observed that, after treatment with $\mathrm{Fe}(\mathrm{VI})\{0.005 \mathrm{mg} / \mathrm{L}\}$ at pH-9 over a period of 25 , COD is decreased to about $65.7 \%$, BOD to $64 \%$, Suspended solids to $22 \%$, phosphate to $57.7 \%$, sulphide to $67.5 \%$, chloride to $28.5 \%$, cyanide to $15 \%$, ammonia to $61.7 \%$, total hardness to $33.5 \%$, arsenic to $33.3 \%$.

\section{Acknowledgment}

The authors acknowledge the support \& encouragement of principal and management of S.E.A college of Engineering and technology, Bangalore. 
Citation: Shastry V, Shashidhar S (2011) Waste Water Treatment Using Eco Friendly Oxidising Agent Fe (VI). Hydrol Current Res 2:123. doi:10.4172/2157-7587.1000123

Page 4 of 4

\section{References}

1. Sharma VK (2002) Potassium ferrate (VI): an environmentally friendly oxidant. Advances in Environmental Research 6: 143-156.

2. Costarramone N, Kneip A, Castetbon A (2004) Ferrate (VI) oxidation of cyanide in water. Environmental technology 25: 945-955.

3. Sharma VK, Jeremy OS, Frank JM (1997) Ferrate(VI) oxidation of hydrogen sulfide. Envioron Sci Technol 31: 2486-2491.

4. Sharma VK, John TB, Joshi VN (1998) Oxidation of ammonia by Ferrate(VI). Journal of environmental Science and health. Part A 33: 635-650.
5. Sharma VK, Mishra SK (2006) Ferrate(VI) oxidation of Ibuprofen. Environ. Chem.Lett 3: 182-185.

6. Lee $Y$ (2009) Environ Sci Technol 43: 3832-3838.

7. Thompson GW, Ockerman LT,Schreyer JM (1951) Preparation and purification of potassium ferrate(VI). J Am Chem Soc 73: 1379-1381.

8. (1999) Standard methods for the examination of water and waste water, 5210 American water works association.

9. Pitwell LR (1983) Standard COD. Chem Brit 19: 907. 